\title{
MAHDOLLISUUKSISTA TUOTTAA SOKERIJUURIKKAAN SIEMENTÄ KASVUPAIKALLAAN TALVEHTINEISTA JUURIKKAISTA SUOMESSA
}

\author{
Juhani Paatela, Helvi Eskola ja Martti Mantere
}

Saapunut 10. 2. 1953

Sokerijuurikas on maamme nuorimpia viljelykasveja, sitä kun on viljelty meillä lähinnä vasta Salon raakasokeritehtaan valmistumisesta, vuodesta 1919 lähtien. Nykyinen viljelyala nousee lähes 15000 hehtaariin. Sokerijuurikkaan viljelyn laajentuessa on syytä kiinnittää huomiota myös sen s i e m e n v i l j e 1 y y n, varsinkin kun tämän kasvin jalostustyötä harjoitetaan maassamme. Siemenviljelysten viljelyala maassamme on nykyisin vain $1-6$ ha, jolta alalta vuosittain saatu 1500 $8000 \mathrm{~kg}: \mathrm{n}$ sato riittää vain n. $70-360$ hehtaarin alalle kylvösiemeneksi. Sokerijuurikkaan viljely maassamme onkin valtaosaltaan tuontisiemenen varassa, jota lähinnä kasvukaudeksi 1951 ostettiin n. $370000 \mathrm{~kg}$ eli n. 31 miljoonan markan arvosta. Maamme lounais- ja eteläosissa on edellytyksiä tuottaa sokerijuurikkaan siementä sen myöhäisestä tuleentumisesta huolimatta, varsinkin suotuisina kasvukausina, joskin siemenen tuotantokustannukset ovat sen hintaan verrattuna suuret. Kustannuksia on omiaan lisäämään erikoisesti istukkaiden aumaaminen syksyllä ja istuttaminen keväällä.

Suomen Raakasokeritehdas Osakeyhtiön koetilalla Kemiössä on vv. 19381941 sokerijuurikkaan siemenviljelyä kokeiltu siten, että istukkaat on jätetty syksyllä kasvupaikkaansa. Talvehtimisen varmentamiseksi juurikkaat on peitetty oljilla. Tämä tapa osoittautui liian työlääksi ja silti hyvin epävarmaksi (1, p. 140). Huolimatta huonoista kokemuksista Suomen Raakasokeritehtaan maille Saloon perustettiin v. 1950 uusi koe, samoin vuosina 1951 ja 1952 Saloon sekä Jokioisiin. Aiheen uusien kokeiden suorittamiseen saitohtori J. PAAtELA Yhdysvalloissa v. 1949, jossa tuotetaan sokerijuurikkaan siementä maassa talvehtineista juurikkaista paitsi useassa eteläisessä valtiossa myös mm. Coloradon ja Utahin osavaltioissa, joissa juurikkaat joutuvat talvikautena kestämään useidenkin asteiden pakkasia $(2,3)$. Meillä em. vuosina suoritetut, tohtori J. Paatelan suunnittelemat kokeet ovat olleet alustavia. Kun niistä kuitenkin on saatu tyydyttäviä siemensatoja, on katsottu aiheelliseksi julkaista tähänastiset tulokset suppeassa muodossa.

Suoritettujen talvehtimiskokeiden päätarkoituksena on ollut selvitellä, millä kehitysasteella sokerijumrikas maassamme parhaiten talvehtii kasvupaikallaan, mikäli 
talvehtiminen lainkaan onnistuu. Kokeet ovat näin ollen kylvöaikakokeita. Käytetty siemen on ollut hollantilaista Kuhn-kantaa. Kylvö on suoritettu SRO:n valmistamalla 2-rivisellä kylvökoneella kylvömäärän ollessa n. 20 kg/ha. Kylvöaikoja oli v. 19505 , vuonna 19513 . Koeruudut ovat olleet $18 \mathrm{~m}^{2}$ :n suuruisia $(20 \times 0.9 \mathrm{~m})$ ja niitä on kylvetty kolme kerrannaista. Kukin koeruutu on jaettu poikittain viiteen neljän metrin pituiseen osaan, joita on lannoitettu eri tavoin. Tällä on pyritty selvittämään lannoituksen vaikutusta sokerijuurikkaan talvehtimisen onnistumiseen. Myös multauksen vaikutusta talvehtimiseen on tutkittu kylvämällä kunakin kylvöaikana kaksi koeruutua, joista toisen taimirivit mullattiin umpeen syksyllä. Kokeita ei ole aina onnistuttu sijoittamaan riittävän yhtenäiselle alueelle, mikä kerrannaisruudustojen vaatimattoman lukumäärän ja ruutujen pienen koon ohella ilmenee selvästi suurissa koevirheissä. Viimeksi mainitut ilmaistaan ainoastaan keskiarvon keskivirheenä. Seuraavassa tarkastellaan tähän mennessä korjatuista sokerijuurikkaan talvehtimiskokeista suoritettuja talvehtimiseen liityviä havaintoja ja saatuja satotuloksia. Niiden lisäksi esitetään tuotettujen siemenerien itävyys ja 1000 siemenen paino.

\section{Vuonna 1950 Saloon perustettu koe}

Vuoden 1950 koe perustettiin seuraavia kylvöaikoja käyttäen: 2.6., 22. 6., 13. 7 , 3. 8. sekä 24. 8. Koe järjestettiin erikseen savi- ja hiekkamultamaalle. Koejäsenet: $\mathrm{A}=$ lannoittamaton, $\mathrm{B}=\mathrm{NPK}, \mathrm{C}=\mathrm{NP}, \mathrm{D}=\mathrm{NK}$ ja $\mathrm{E}=\mathrm{PK} . \mathrm{N}=800 \mathrm{~kg} / \mathrm{ha}$ kalkkisalpietaria, $\mathrm{P}=1000 \mathrm{~kg} /$ ha superfosfaattia sekä $\mathrm{K}=600 \mathrm{~kg} / \mathrm{ha} 40 \%$ :sta kalisuolaa. Kesän 1950 kuivuudesta johtuen taimettuivat kylvöt epätasaisesti ja osittain erittäin heikosti. Savimultamaa oli hiljattain suoritetun salaojituksen jäljiltä epätasainen, hiekkamaalla taas kosteusolot vaihtelivat suuresti maan kaltevuudesta johtuen (A-ruudut kuivimmalla ja E-ruudut tuoreimmalla kohdalla). Lokakuun lopulla (27.10.50) määritettiin juurien keskimääräinen läpimitta eri koejäsenien ruuduilla. Tulokset käyvät ilmi erikseen savi- ja hiekkamultamaiden kokeiden osalta seuraavasta asetelmasta:

Juurien keskimääräinen läpimitta $\mathrm{cm}$

1. kylvö 2.6. 2. kylvö 22.6. 3. kylvö 13. 7 .

$$
\begin{aligned}
& \mathrm{A}=\mathrm{O} \\
& \mathrm{B}=\mathrm{NPK} \\
& \mathrm{C}=\mathrm{NP} \\
& \mathrm{D}=\mathrm{NK} \\
& \mathrm{E}=\mathrm{PK}
\end{aligned}
$$$$
\text { A-E keskim. }
$$

A
B
C
D
E
A-E keskim.

2.2
3.0
2.8
3.0
3.8
$\mathbf{3 . 0}$

$\mathrm{Savimultam} \mathrm{a}$

$\begin{array}{ll}3.3 & 1.6 \\ 4.0 & 2.2 \\ 2.7 & 1.3 \\ 3.0 & 2.0 \\ 2.7 & 1.7 \\ 3.1 & 1.8\end{array}$

$\mathrm{Hi}$ e k k m u $\mathrm{lt}$ a m a a

$\begin{array}{ll}2.9 & 2.0 \\ 3.5 & 2.4 \\ 3.0 & 3.0 \\ 4.0 & 2.8 \\ 3.8 & 2.5 \\ 3.4 & \mathbf{2 . 5}\end{array}$


4. ja 5. kylvössä kehittyneiden yksilöiden juuret olivat jokseenkin saman kokoisia, n. $0.2 \mathrm{~cm}: \mathrm{n}$ paksuisia.

Syksyllä 1950 ja keväällä 1951 suoritettujen aukkomittausten mukaan on laskettu eri koejäsenien talvehtimisprosentit erikseen multaamattomien ja mullattujen ruutujen osalta. Tulokset esitetään seuraavassa asetelmassa:

M u l t a a m aton

1. kylvö

2. 6 .

2. kylvö

22. 6 .

61

60

58

59

59

A-E keskim.

59

A

B

35

51

89

87

D

E

A-E keskim.
75

67
3. kylvö ${ }^{1}$ ) 13. 7 .

Savimult a m a

$\begin{array}{llll}86 & 32 & 48 & 68 \\ 78 & 42 & 67 & 68 \\ 78 & 47 & 71 & 88 \\ 88 & 61 & 53 & 85 \\ 68 & 55 & 64 & 86 \\ \mathbf{8 0} & \mathbf{4 7} & \mathbf{6 1} & \mathbf{7 9}\end{array}$

$\mathrm{Hi}$ e k k m u lta ma a

$\begin{array}{llll}60 & 53 & 57 & 86 \\ 84 & 60 & 75 & 89 \\ 94 & 86 & 83 & 90 \\ 91 & 83 & 89 & 89 \\ 92 & 87 & 86 & 85 \\ \mathbf{8 4} & \mathbf{7 4} & \mathbf{7 8} & \mathbf{8 8}\end{array}$

Asetelman lukuja tarkasteltaessa voidaan mm. todeta, että juurikkaiden talvehtimisprosentti näyttää selvästi nousevan multaamattomien ja mullattujen ruutujen kohdalla sekä hiekka- että savimultamaalla 1. kylvöajasta kolmanteen siirryttäessä. Kun juurien keskimääräinen läpimitta samalla on pienentynyt $3.0-4.4 \mathrm{~cm}$ :stä $1.8-$ $2.5 \mathrm{~cm}$ :iin, viimeksi mainitun kokoiset juuret ovat siis talvehtineet paremmin kuin niitä suuremmat (kuva 1). 4. ja 5. kylvön juuret sen sijaan, joiden läpimitta oli vain n. $0.2 \mathrm{~cm}$, tuhoutuivat kokonaan talven aikana verraten edullisista talvehtimisoloista huolimatta. $\left.{ }^{2}\right)$ Toisaalta voidaan todeta, että hiekkamultamaalla juuret ovat talvehtineet jonkin verran paremmin kuin savimultamaalla, vaikka savimaan juurikkaat ovat olleet jokaisen kylvöajan kohdalla jonkin verran hiekkamultamaan juurikkaita pienemmät. Multaus näyttää hiukan huonontaneen talvehtimista savimultamaalla ja parantaneen talvehtimista hiekkamultamaalla. Erot eivät kuitenkaan ole

1) 4. ja 5. kylvön taimet tuhoutuivat kokonaan talven aikana. - ${ }^{2}$ ) Katso nuotti seur. siv.

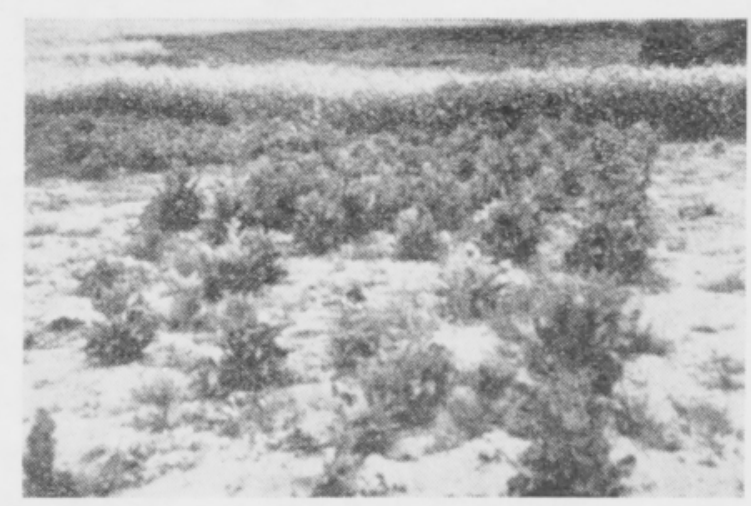

Kuva 1. Talvehtineita sokerijuurikkaita 18. 6. 51. Kylvetty 13. 7. 50.

Figure 1. Overwintered beets in June 18 , 1951. Date of seeding July 13, 1950.

H. Eskola. 
kovin selvät, varsinkaan keskiarvotulosten kohdalla. Lannoituksen vaikutus talvehtimiseen ei käy tuloksista ilmi. Erilaisten kasvuolojen vaikutus hiekkamaan kokeessa tekee sitäpaitsi mahdottomaksi eri lannoiteruutujen välisen vertailun. - Kokeet niitettiin 4-6.9., sato ulkokuivattiin seipäillä ja siemenet riivittiin syksyn kuluessa sekä lajiteltiin. Millaisia siemensatoja 1-3. kylvöjen ruuduilta saatiin savi- ja hiemmamultamailla, selviää taulukoista 1 ja 2 , joissa myös esitetään siemenerien itävyys ja 1000 siemenen paino.

Kuten taulukosta 1 käy ilmi, tahvehtineista multaamattomista juurikkaista on saatu yleensä hyviä, jopa erinomaisia siemensatoja. Siementen koko ja itävyys on niin ikään ollut varsin tyydyttävä. Kaikkien multaamattomien koejäsenten $\mathrm{A}-\mathrm{E}$ keskimääräisten tulosten mukaan on 1. ja 2. kylvöstä saatu selvästi suurimmat siemensadot (2 407 ja $2409 \mathrm{~kg} / \mathrm{ha}$ ) siitä huolimatta, että ao. kasvustojen talvehtimisprosentit olivat pienemmät (59 ja $64 \%$ ) kuin 3. kylvön kohdalla ( $80 \%$ ), josta saatiin $1562 \mathrm{~kg} /$ ha siementä. Pienet juurikkaat sisältävät vähemmän ravinteita kuin suuremmat, joten riittävän hyvin talvehtineina viimeksi mainituista saadut suuremmat siemensadot ovat helposti ymmärrettävissä.

Multaaminen on vaikuttanut erikoisen haitallisesti satotuloksiin, ja sitä selvemmin, mitä myöhäisemmästä kylvöstä on kysymys. Kun 1. kylvön mullatuista ruuduista on saatu vielä keskimäärin $1546 \mathrm{~kg} / \mathrm{ha}$ siementä ja 2 . kylvön ruuduista $1418 \mathrm{~kg} / \mathrm{ha}$, on 3 . kylvön sato pienentynyt varsin mitättömäksi ollen enää $214 \mathrm{~kg} / \mathrm{ha}$. Kun mullattujen ja multaamattomien kasvustojen talvehtimisessa ei ollut sanottavia eroja, johtunee mullattujen ruutujen huonompi sato pääasiassa siitä, että juurikkaat pääsivät myöhemmin kasvun alkuun kuin multaamattomat ja että pienet juu-

\begin{tabular}{|c|c|c|c|c|c|c|}
\hline & & & $\begin{array}{l}\text { Keskilämpötila } \\
{ }^{\circ} \mathrm{C}\end{array}$ & $\begin{array}{l}\text { Alin lämpötila } \\
\text { maan pinnassa } \\
{ }^{\circ} \mathrm{C}\end{array}$ & $\begin{array}{l}\text { Sademäärä } \\
\text { mm }\end{array}$ & $\begin{array}{l}\text { Lumipeitteen } \\
\text { keskim. } \\
\text { vahvuus cm }\end{array}$ \\
\hline \multirow[t]{9}{*}{1950} & Lokakuu & $1-10$ & 11.0 & $-2.4-8.6$ & 24 & - \\
\hline & & $11-20$ & 8.4 & $-2.0-+8.1$ & 47 & - \\
\hline & & $21-31$ & 3.0 & $-9.0-+2.2$ & 14 & - \\
\hline & Marraskuu & $1-10$ & 1.8 & $-3.7-+2.7$ & 20 & 2 \\
\hline & & $11-20$ & 2.7 & $-5.9-+1.0$ & 51 & 1 \\
\hline & & $21-30$ & 1.9 & $-4.2-+3.2$ & 27 & 0 \\
\hline & Joulukuu & $1-10$ & 0.0 & $-13.9--0.5$ & 52 & 8 \\
\hline & & $11-20$ & 3.2 & $-1.0-+2.5$ & 34 & 0 \\
\hline & & $21-31$ & -6.2 & $-25.7--0.6$ & 12 & 4 \\
\hline \multirow[t]{12}{*}{1951} & Tammikuu & $1-10$ & -5.8 & $-12.7--3.0$ & 26 & 14 \\
\hline & & $11-20$ & -1.3 & $-13.2--0.5$ & 30 & 18 \\
\hline & & $21-31$ & -9.0 & $-28.4--4.3$ & 4 & 20 \\
\hline & Helmikuu & $1-10$ & -3.5 & $-13.5--0.6$ & 17 & 23 \\
\hline & & $11-20$ & -6.2 & $-26.6--0.8$ & 5 & 23 \\
\hline & & $21-28$ & -4.7 & $-15.1--2.3$ & 6 & 24 \\
\hline & Maaliskuu & $1-10$ & -3.9 & $-17.9--4.6$ & 2 & 31 \\
\hline & & $11-20$ & -8.1 & $-34.1--7.2$ & 15 & 37 \\
\hline & & $21-31$ & -2.0 & $-23.7--0.6$ & 26 & 67 \\
\hline & Huhtikuu & $1-10$ & 2.1 & $-11.7-+0.2$ & 23 & 44 \\
\hline & & $11-20$ & 2.0 & $-3.7-+0.9$ & 34 & 6 \\
\hline & & $21-30$ & 8.4 & $-3.4-+8.0$ & 0 & - \\
\hline
\end{tabular}


Taulukko 1. Sokerijuurikkaan talvehtimiskoe savimultamaalla Salossa v. 1950/51. Siemensadot ja sadon laatu.

Table 1. Overwintering experiment with sugar beet on clay mould at Salo in 1950/51. Yields and quality of seed.

\begin{tabular}{|c|c|c|c|c|c|c|c|c|c|}
\hline & \multicolumn{3}{|c|}{$\begin{array}{l}\text { 1. kylvö } 2 / 6 \\
1 \text { st seeding }\end{array}$} & \multicolumn{3}{|c|}{$\begin{array}{l}\text { 2. kylvö } 22 / 6 \\
2 \text { nd seeding }\end{array}$} & \multicolumn{3}{|c|}{$\begin{array}{c}\text { 3. kylvö } 13 / 7 \\
\text { 3rd seeding }\end{array}$} \\
\hline & & & 1000 & & & 1000 & & & 1000 \\
\hline Koejäsen & $\begin{array}{l}\text { Siemen- } \\
\text { sato }\end{array}$ & $\begin{array}{l}\text { Itä- } \\
\text { vyys }\end{array}$ & $\begin{array}{c}\text { s.p. } \\
\text { Weight }\end{array}$ & $\begin{array}{l}\text { Siemen- } \\
\text { sato }\end{array}$ & $\begin{array}{l}\text { Itä- } \\
\text { vyys }\end{array}$ & $\begin{array}{l}\text { s.p. } \\
\text { Weight }\end{array}$ & $\begin{array}{l}\text { Siemen- } \\
\text { sato }\end{array}$ & $\begin{array}{l}\text { Itä- } \\
\text { vyys }\end{array}$ & $\begin{array}{c}\text { s.p. } \\
\text { Weight }\end{array}$ \\
\hline Treatment & $\begin{array}{l}\text { Yield } \\
\text { of seed } \\
\mathrm{kg} / \mathrm{ha}\end{array}$ & $\begin{array}{c}\text { Germi- } \\
\text { nation } \\
\%\end{array}$ & $\begin{array}{c}\text { of } 1000 \\
\text { seeds } \\
\mathrm{g}\end{array}$ & $\begin{array}{c}\text { Yield } \\
\text { of seed } \\
\mathrm{kg} / \mathrm{ha}\end{array}$ & $\begin{array}{c}\text { Germi- } \\
\text { nation } \\
\%\end{array}$ & $\begin{array}{c}\text { of } 1000 \\
\text { seeds } \\
\mathrm{g}\end{array}$ & $\begin{array}{c}\text { Yield } \\
\text { of seed } \\
\mathrm{kg} / \mathrm{ha}\end{array}$ & $\begin{array}{c}\text { Germi- } \\
\text { nation } \\
\%\end{array}$ & $\begin{array}{c}\text { of } 1000 \\
\text { seeds } \\
\mathrm{g}\end{array}$ \\
\hline
\end{tabular}

\begin{tabular}{|c|c|c|c|c|c|c|c|c|c|}
\hline & & & M u & ta a mator & & $o v e$ & & & \\
\hline$A=O$ & $1909 \pm 373$ & 92 & 19.0 & $2358 \pm 439$ & 87 & 18.8 & $1282 \pm 179$ & 91 & 18.5 \\
\hline$B=N P K$ & $2794 \pm 345$ & 91 & 17.5 & $2379 \pm 330$ & 89 & 16.5 & $2288 \pm 82$ & 94 & 18.0 \\
\hline $\mathrm{C}=\mathrm{NP}$ & $2752 \pm 585$ & 96 & 18.5 & $2267 \pm 688$ & 94 & 19.3 & $1909 \pm 185$ & 99 & 20.5 \\
\hline $\mathrm{D}=\mathrm{NK}$ & $2682 \pm 494$ & 87 & 17.5 & $3055 \pm 261$ & 96 & 16.8 & $1158 \pm 252$ & 93 & 18.5 \\
\hline $\mathrm{E}=\mathrm{PK}$ & $1900 \pm 379$ & 90 & 18.3 & $1985 \pm 255$ & 90 & 18.0 & $1173 \pm 239$ & 87 & 17.8 \\
\hline $\begin{array}{l}\text { Keskim. } \\
\text { Average }\end{array}$ & $2407 \pm 434$ & 91 & 18.2 & $2409 \pm 395$ & 91 & 17.9 & $1562 \pm 143$ & 93 & 18.7 \\
\hline & & & & $\mathrm{Mul} 1 \mathrm{lat} \mathrm{tu}$ & Co & & & & \\
\hline $\mathrm{A}$ & $1071 \pm 408$ & 90 & 19.5 & $992 \pm 463$ & 91 & 17.8 & $376 \pm 89$ & 80 & 18.3 \\
\hline B & $1587 \pm 29$ & 88 & 17.3 & $1653 \pm 492$ & 92 & 18.5 & $368 \pm 171$ & 83 & 18.5 \\
\hline C & $1350 \pm 132$ & 92 & 17.3 & $1413 \pm 161$ & 94 & 19.5 & $158 \pm 37$ & 85 & 19.5 \\
\hline $\mathrm{D}$ & $1784 \pm 516$ & 89 & 17.8 & $1447 \pm 334$ & 96 & 19.0 & $0-$ & - & -- \\
\hline E & $1939_{ \pm 266}$ & 92 & 17.0 & $1587 \pm 524$ & 92 & 18.3 & $166 \pm 18$ & 92 & 17.5 \\
\hline $\begin{array}{l}\text { Keskim. } \\
\text { Average }\end{array}$ & $1546 \pm 270$ & 90 & 17.8 & $1+18 \pm 395$ & 93 & 18.6 & $214 \pm 63$ & 8.5 & 18.6 \\
\hline
\end{tabular}

rikkaat ovat kärsineet multaamisesta enemmän kuin runsaammin vararavinteita sisältävät suuremmat juurikkaat. Tämä siitäkin huolimatta, että liika maa haravoitiin mullattujen juurikkaiden päältä keväällä, ja että niille annettiin $200 \mathrm{~kg} / \mathrm{ha}$ salpietaria. Siemensadon laatuun multaus ei kuitenkaan näytä ainakaan selvästi vaikuttaneen.

Myös hiekkamultamaalla tahvehtineista multaamattomista juurikkaista on saatu yleensä hyviä, jopa suurempia satoja kuin savimultamaalla (taulukko 2). Kun kaikkien kylvöaikojen juurikkaat talvehtivat varsin tyydyttävästi $(67-84 \%$ multaamattomilla ja $74-88 \%$ mullatuilla ruuduilla), eli jonkin verran paremmin kuin savimultamaalla, ja kun juurikkaiden keskikokokin oli hiekkamultamaalla suurempi (halkaisija 2.5-4.4 cm) kuin savimultamaalla $(1.8-3.1 \mathrm{~cm}$ ), on niiden suurempi satokin (2 $340-3239 \mathrm{~kg} / \mathrm{ha}$ ) hyvin ymmärrettävissä. Myös hiekkamultamaalla multaaminen on vaikuttanut hyvin haitallisesti satotuloksiin (1 409-2 340 $\mathrm{kg} / \mathrm{ha}$ ), joskaan eri kylvöaikojen välillä ei ole todettavissa yhtä selviä eroja kuin savimultamaalla. Kun hiekkamultamaalla ei myöskaan ollut oleellisia eroja multaamattomien ja mullattujen juurikkaiden talvehtimisessa, on siis multaaminen selvästi alentanut siemensatoja. Siemensadon itävyys on ollut jonkin verran pienempi kuin 
Taulukko 2. Sokerijuurikkaan talvehtimiskoe hiekkamultamaalla Salossa v. 1950/51. Siemensadot ja sadon laatu.

Table 2. Overwintering experiment with sugar beet on sand mould at Salo in 1950/51. Yields and quality of seed.

\begin{tabular}{|c|c|c|c|c|c|c|c|c|c|}
\hline \multirow[b]{2}{*}{ Koejäsen } & \multicolumn{3}{|c|}{$\begin{array}{l}\text { 1. kylvö } 2 / 6 \\
1 \text { st seeding }\end{array}$} & \multicolumn{3}{|c|}{$\begin{array}{l}\text { 2. kylvö } 22 / 6 \\
2 \text { nd seeding }\end{array}$} & \multicolumn{3}{|c|}{$\begin{array}{c}\text { 3. kylvö } 13 / 7 \\
\text { 3rd seeding }\end{array}$} \\
\hline & $\begin{array}{c}\text { Siemen- } \\
\text { sato } \\
\text { Yield } \\
\text { of seed } \\
\mathrm{kg} / \mathrm{ha}\end{array}$ & $\begin{array}{c}\text { Itä- } \\
\text { vyys } \\
\text { Germi- } \\
\text { nation } \\
\%\end{array}$ & $\begin{array}{c}1000 \\
\text { s.p. } \\
\text { Weight } \\
\text { of } 1000 \\
\text { seeds } \\
\text { g }\end{array}$ & $\begin{array}{c}\text { Siemen- } \\
\text { sato } \\
\text { Yield } \\
\text { of seed } \\
\mathrm{kg} / \mathrm{ha}\end{array}$ & $\begin{array}{c}\text { Itä- } \\
\text { vyys } \\
\text { Germi- } \\
\text { nation } \\
\%\end{array}$ & $\begin{array}{c}1000 \\
\text { s.p. } \\
\text { Weight } \\
\text { of } 1000 \\
\text { seeds } \\
\text { g }\end{array}$ & $\begin{array}{c}\text { Siemen- } \\
\text { sato } \\
\text { Yield } \\
\text { of seed } \\
\mathrm{kg} / \mathrm{ha}\end{array}$ & $\begin{array}{c}\text { Itä- } \\
\text { vyys } \\
\text { Germi- } \\
\text { nation } \\
\% \\
\end{array}$ & $\begin{array}{c}1000 \\
\text { s.p. } \\
\text { Weight } \\
\text { of } 1000 \\
\text { seeds } \\
\text { g } \\
\end{array}$ \\
\hline \multicolumn{10}{|c|}{ Multa a maton Uncovered } \\
\hline $\mathrm{A}=\mathrm{O}$ & $976 \pm 179$ & 54 & 16.8 & $545 \pm 176$ & 46 & 16.0 & $1121 \pm 452$ & 54 & 19.3 \\
\hline $\mathrm{B}=\mathrm{NPK}$ & $1964 \pm 236$ & 73 & 18.3 & $1712 \pm 221$ & 69 & 18.8 & $2070 \pm 155$ & 68 & 19.0 \\
\hline $\mathrm{C}=\mathrm{NP}$ & $4282 \pm 403$ & 84 & 18.8 & $2676 \pm 303$ & 84 & 20.3 & $3733 \pm 664$ & 77 & 19.0 \\
\hline $\mathrm{D}=\mathrm{NK}$ & $5242 \pm 1188$ & 82 & 19.0 & $3076 \pm 73$ & 89 & 18.8 & $4582 \pm 333$ & 85 & 18.3 \\
\hline $\mathrm{E}=\mathrm{PK}$ & $4561 \pm 915$ & 88 & 19.0 & $3691 \pm 388$ & 87 & 20.0 & $4688 \pm 45$ & 86 & 21.8 \\
\hline Keskim. & $3405 \pm 584$ & 76 & 18.4 & $2340 \pm 234$ & 75 & 18.8 & $3239 \pm 330$ & 74 & 19.5 \\
\hline \multicolumn{10}{|c|}{ M u llattu Covered } \\
\hline A & $945 \pm 476$ & 62 & 19.5 & $561 \pm 148$ & 59 & 19.3 & $1036 \pm 242$ & 54 & 17.0 \\
\hline B & $2091 \pm 633$ & 73 & 17.8 & $1006 \pm 245$ & 62 & 16.5 & $1545 \pm 291$ & 73 & 17.5 \\
\hline $\mathrm{C}$ & $1776 \pm 424$ & 75 & 16.5 & $968 \pm 66$ & 73 & 18.3 & $1895 \pm 213$ & 81 & 19.3 \\
\hline $\mathrm{D}$ & $3197 \pm 442$ & 88 & 19.0 & $1816 \pm 108$ & 85 & 18.0 & $2163 \pm 253$ & 90 & 20.8 \\
\hline $\mathrm{E}$ & $3692 \pm 692$ & 87 & 18.0 & $2692 \pm 242$ & 90 & 18.8 & $2876 \pm 587$ & 90 & 19.3 \\
\hline $\begin{array}{l}\text { Keskim. } \\
\text { Average }\end{array}$ & $2340 \pm 533$ & 78 & 18.2 & $1409 \pm 162$ & 74 & 18.2 & $1903 \pm 317$ & 78 & 18.8 \\
\hline
\end{tabular}

savimultamaalla, mikä johtunee nimenomaan lannoittamattomilta ruuduilta (koejäsen A) saatujen satojen melko alhaisesta itävyydestä (46-62\%), ao. ruudut kun kärsivät selvimmin kuivuudesta. Tämä käy ilmi myös 1000. siemenen painosta.

\section{Vuonna 1951 Saloon perustettu koe}

Vuoden 1951 koe perustettiin hiekkamultamaalle seuraavia kylvöaikoja käyttäen: 28. 6., 13. 7. ja 3. 8. Koejäsenet ovat samat kuin vuoden 1950 kokeessa. Kaksi ensimmäistä kylvöä suoritettiin edullisten sääolojen vallitessa, joten taimistot kehittyivät melko tasaisiksi ja reheviksi. Myöhemmin syksyllä kuivuus hidastutti kasvua. Koealueen oikeanpuoleisessa osassa maalaji oli selvästi kevyintä, joten kuivuus vaikutti haitallisimmin siinä osassa koetta. Syyskuun 5. päivänä suoritettujen mittausten mukaan naatin korkeus oli kokeen vasemmanpuoleisen osan 1. kylvön ruuduissa keskimäärin $49 \mathrm{~cm}$ ja 2 . kylvön ruuduissa $38 \mathrm{~cm}$, oikeanpuoleisessa osassa vastaavasti 34 ja $28 \mathrm{~cm}$. Kolmas kylvö kehittyi alunperin kuivuuden takia heikommin ja taimisto jäi paikoitellen varsin aukkoiseksi ja pieneksi. Maalajin vaihtelusta johtuvat erot olivat samasta syystä vielä tuntuvammat kuin 1. ja 2. kylvössä. Naatin korkeus vaihteli $3-15 \mathrm{~cm}$ ollen vasemmanpuoleisessa osassa keskimäärin $12 \mathrm{~cm}$ 
ja oikeanpuoleisessa osassa $5 \mathrm{~cm}$. Erilaisella lannoituksella ei näyttänyt olevan silminnähtävää vaikutusta naattien eikä juurien kokoon. Lokakuun 19. päivänä suoritettujen mittausten mukaan vaihteli juurien läpimitta 1 . kylvössä $3.5-6 \mathrm{~cm}$ (ollen keskinaärin n. $4 \mathrm{~cm}$ ), 2. kylvössä $2-4 \mathrm{~cm}$ (keskimäärin n. $2.5 \mathrm{~cm}$ ) ja kolmannessa kylvössä $0.2-1 \mathrm{~cm}$ (keskimäärin $0.5 \mathrm{~cm}$ ). Kokeen oikeanpuoleinen osa mullattiin 22. 10 .

Kasvusto paljastui lumesta huhtikuun alkupuoliskolla, mutta kasvu alkoi vasta noin kuukautta myöhemmin. Talven aikana olivat kaikkein suurimmat ja pienimmät yksilöt kuolleet, joten 2. kylvö, jossa näitä juurikkaita oli vähiten, näytti säilyneen parhaiten. Erilaisella lannoituksella ei ollut silminnähtävää vaikutusta talvehtimiseen. Miten sääolot vaihtelivat talvikauden aikana, selviää allaolevasta asetelmasta:

\begin{tabular}{|c|c|c|c|c|c|c|}
\hline & & & $\begin{array}{c}\text { Keskilämpötila } \\
{ }^{\circ} \mathrm{C}\end{array}$ & $\begin{array}{l}\text { Alin lämpötila } \\
\text { maan pinnassa } \\
{ }^{\circ} \mathrm{C}\end{array}$ & $\begin{array}{c}\text { Sademäärä } \\
\mathrm{mm}\end{array}$ & $\begin{array}{l}\text { Lumipeitteen } \\
\text { keskim. } \\
\text { vahvuus } \mathrm{cm}\end{array}$ \\
\hline \multirow[t]{9}{*}{1951} & Lokakuu & $1-10$ & 8.7 & $-4.2-+7.5$ & 0 & - \\
\hline & & $11-20$ & 8.5 & $-6.1-+7.7$ & 0 & - \\
\hline & & $21-31$ & 6.3 & $-8.7-+6.3$ & 7 & \\
\hline & Marraskuu & $1-10$ & 1.4 & $-8.5-+5.2$ & 11 & 0 \\
\hline & & $11-20$ & -0.3 & $-11.3-+2.9$ & 13 & 0 \\
\hline & & $21-30$ & 3.0 & $-13.0-+4.6$ & 54 & - \\
\hline & Joulukuu & $1-10$ & -0.4 & $-13.7-+1.0$ & 44 & 1 \\
\hline & & $11-20$ & -0.2 & $-15.0-+2.4$ & 17 & 2 \\
\hline & & $21-31$ & 2.9 & $-5.2-+4.0$ & 23 & - \\
\hline \multirow[t]{12}{*}{1952} & Tammikuu & $1-10$ & 0.5 & $-16.7-+0.5$ & 22 & 1 \\
\hline & & $11-20$ & -1.9 & $-16.5--0.5$ & 23 & 5 \\
\hline & & $21-31$ & -4.5 & $-17.9--2.6$ & 12 & 24 \\
\hline & Helmikuu & $1-10$ & -2.0 & $-16.0--2.2$ & 15 & 23 \\
\hline & & $11-20$ & -3.9 & $-24.7--2.1$ & 8 & 34 \\
\hline & & $21-29$ & -5.9 & $-23.8--1.3$ & 9 & 30 \\
\hline & Maaliskuu & $1-10$ & -5.2 & $-25.1--3.5$ & 8 & 39 \\
\hline & & $11-20$ & -6.3 & $-31.9--0.8$ & 10 & 37 \\
\hline & & $21-31$ & -9.7 & $-32.1--15.7$ & 2 & 41 \\
\hline & Huhtikuu & $1-10$ & 0.9 & $-21.3-+0.6$ & 12 & 31 \\
\hline & & $11-20$ & 4.7 & $-7.3-+0.5$ & 1 & 1 \\
\hline & & $21-30$ & 10.3 & $-2.2-+9.8$ & 8 & - \\
\hline
\end{tabular}

Asetelman tuloksia tarkasteltaessa voidaan todeta, että juurikkaat eivät yleensä ole joutuneet talvehtimaan kovien pakkasien aikana ilman suojaavaa lumipeitettä. Talvehtimisprosentit laskettiin 21. 5. suoritettujen mittausten mukaan, jolloin naattien pituus vaihteli kymmenen sentin molemmin puolin. Ne esitetään seuraavalla sivulla olevassa asetelmassa erikseen multaamattomien ja mullattujen ruutujen osalta:

Multaus näyttää selvästi parantaneen 1 . kylvön (78 ja $46 \%$ ), jossain määrin myös 2. kylvön (75 ja $60 \%$ ) juurikkaiden talvehtimista. Sen sijaan 3. kylvön juurikkaat ovat talvehtineet parhaiten multaamattominá ( 66 ja $52 \%$ ). Kun 3. kylvön 
M u l t a a m aton

1. kylvö

28. 6 .

2. kylvö

13.7 .

3. kylvö

3.8 .

Talvehtimisprosentti

$\begin{array}{cc}\mathrm{A} & 51 \\ \mathrm{~B} & 37 \\ \mathrm{C} & 45 \\ \mathrm{D} & 46 \\ \mathrm{E} & 53 \\ \text { Keskim. } & \mathbf{4 6}\end{array}$

51

37

45

46

53
$\mathbf{4 6}$

66
54
58
53
70
60

66

54

58

53

60
M u 11 a t t u

2. kylvö

13. 7 .

3. kylvö

28. 6 .

81
73
75
78
81
78

$\begin{array}{ll}65 & 54 \\ 82 & 37 \\ 75 & 50 \\ 72 & 46 \\ 81 & 71 \\ 75 & 52\end{array}$

juurikkaiden läpimitta ei ollut syksyllä kuin keskimäärin n. $0.5 \mathrm{~cm}$, ovat pienet juurikkaat vähän ravinteita sisältävinä selvästi kärsineet multauksesta, kuten edellisenäkin vuotena.

Kukinta alkoi heinäkuun alkupäivinä (kuvat 2 ja 3). Tähän mennessä varsinkin kokeen mullatun osan kasvusto oli joutunut kärsimään alkukesän kuivuudesta, jonka
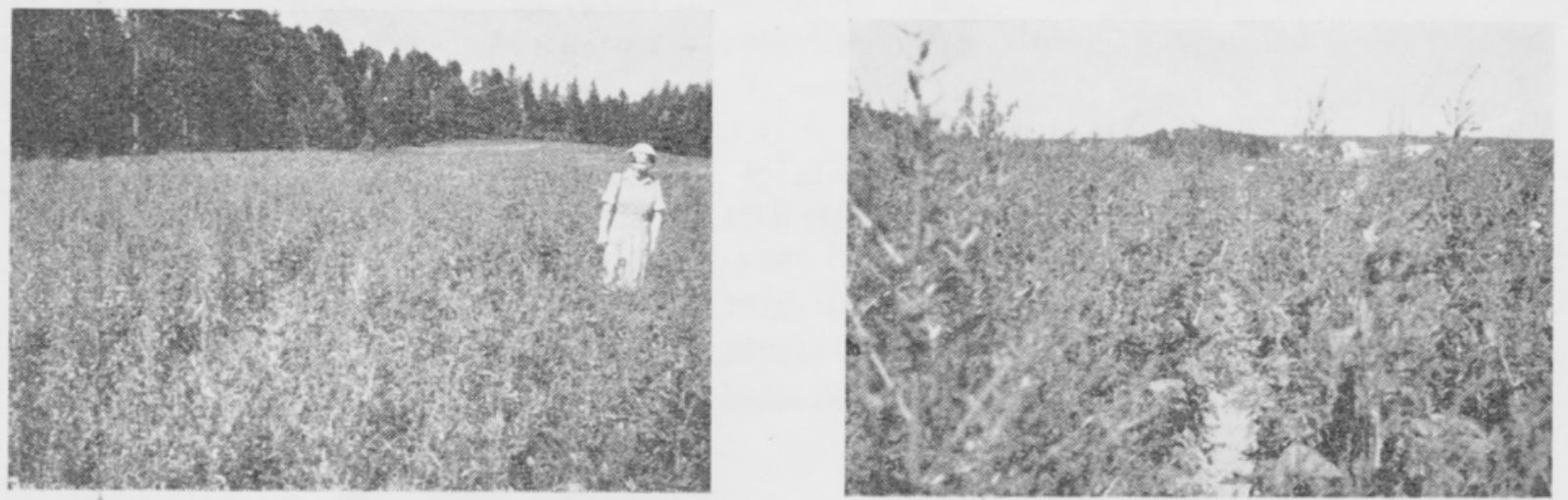

Kuvat 2-3. Sokerijuurikkaan talvehtimiskoe Salossa v. 1951/52 kukkimisen alkaessa 7. 7.52 Figures 2-3. Overwintering experiment with sugar beet at Salo in 1951/52 at early bloom, July 7 .

J. Paatela.

vuoksi kasvusto oli epätasaista ja pienenpuoleista. Multaamattomassa osassa sen sijaan oli muutamia varsin hyviäkin ruutuja. Kukinta kesti epäedullisten sääolojen takia kauan, ja yksilöihin alkoi kasvaa runsaasti sivuversoja, mikä hidastutti tuleentumista. Heikosti ja epätasaisesti tuleentunut kasvusto niitettiin 12-13.9., kuivatettiin seipäillä, riivittiin ja siemensato lajiteltiin. Satotulokset selviävät taulukosta 3, jossa myös esitetään siemenerien itävyysprosentit ja 1000. siemenen painot.

Kuten taulukosta 3 käy ilmi, talvehtineista multaamattomista juurikkaista on saatu hyviä, jopa erinomaisia siemensatoja. Siementen koko on edellisen vuoden keskikokoon (1000 siemenen paino n. $18 \mathrm{~g}$ ) verrattuna suuri (n. $25 \mathrm{~g}$ ), mutta itävyys epätyydyttävän tuleentumisen vuoksi varsin alhainen, keskimäärin $55 \%$ (edellisenä vuotena savimultamaalla n. 91 ja hiekkamultamaalla n. $76 \%$ ). 1. ja 2 . multaamattomasta kylvöstä on saatu selvästi suurimmat siemensadot (2 753 ja $2342 \mathrm{~kg} / \mathrm{ha}$ ) siitä huolimatta, että ao. kasvustojen talvehtimisprosentit olivat jonkin verran pienemmät (46 ja $60 \%$ ) kuin 3 . kylvön kohdalla (66\%), josta saatiin siementä $1725 \mathrm{~kg} / \mathrm{ha}$. 
Taulukko 3. Sokerijuurikkaan talvehtimiskoe Salossa v. 1951/52. Siemensadot ja sadon laatu. Table 3. Overwintering experiment with sugar beet at Salo in 1951/52. Yields and quality of seed.

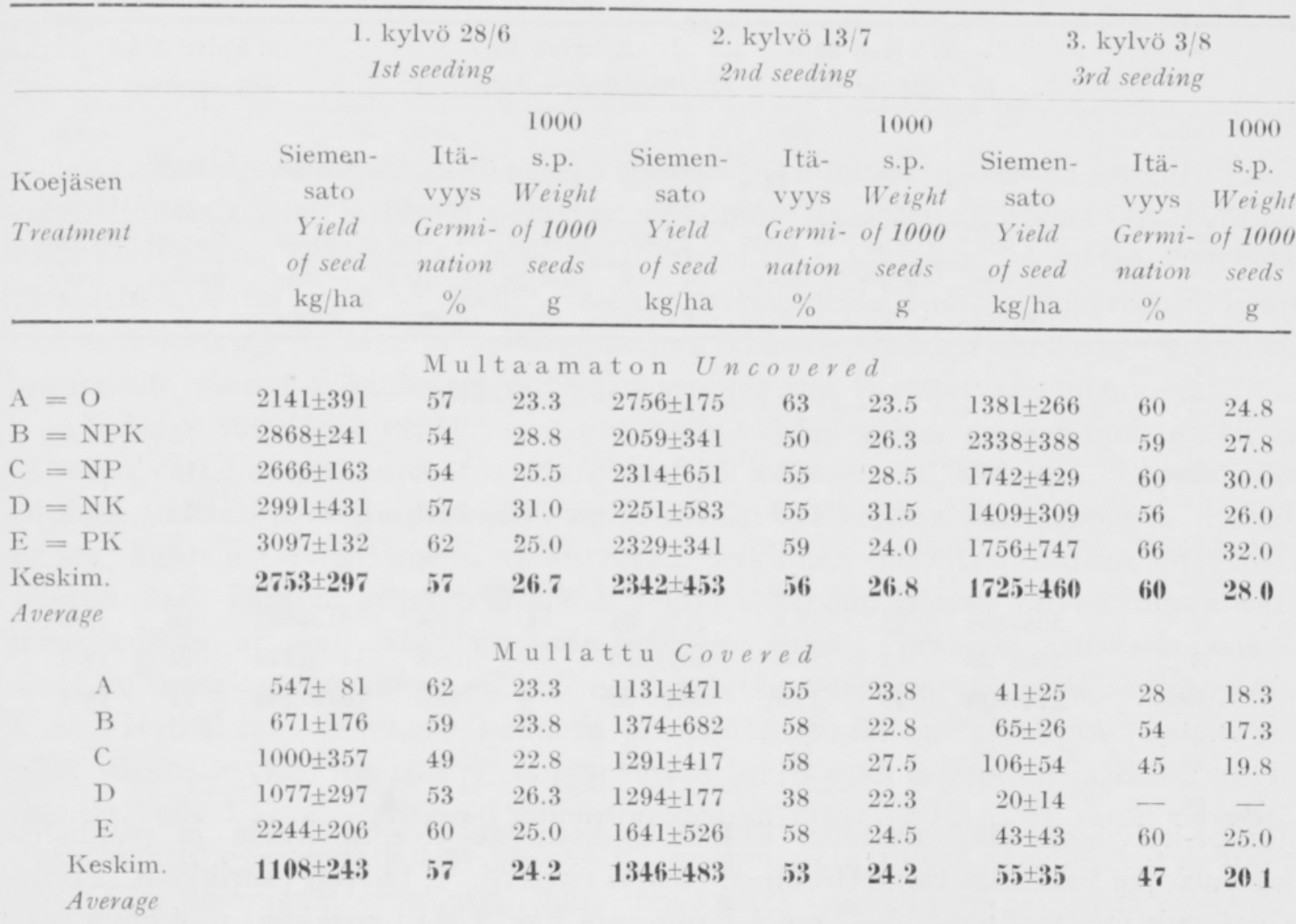

Tähän lienee vaikuttanut pääasiassa juurikkaiden verraten pieni koko, kuten myös vuoden 1950/51 kokeen tulosten tarkastelussa pääteltiin.

Multaaminen on vaikuttanut erittäin haitallisesti satotuloksiin, nimenomaan 3. kylvön kohdalla. Siemensadot vaihtelivat 1-3. kylvöjen osalta seuraavasti: 1 108, 1346 ja $55 \mathrm{~kg} / \mathrm{ha}$. Vaikka multaaminen paransi 1. kylvön kasvustojen talvehtimista varsin tuntuvasti (46 ja $78 \%$ ), 1. kylvön mullatulta alalta saatiin yli puolta pienempi siemensato (1 $108 \mathrm{~kg} / \mathrm{ha})$ kuin vastaavalta multaamattomalta alalta $(2753 \mathrm{~kg} / \mathrm{ha})$. Tuloksia ei tosin voida suoraan verrata toisiinsa, koska mullatut ruudut sijaitsivat koealueen huonoimmassa osassa. Näyttää kuitenkin siltä, että siemensadon kannalta ei ole tärkeintä se, miten hyvin kasvusto talvehtii, vaan se, että talvehtineita juurikkaita jää riittävästi peltoon tuottamaan siementä. Kun juurikkaat kasvavat kylvökesänä harventamattomina, saattaa olla edullistakin siemensadon kannalta, että osa yksilöistä karsiutuu talven aikana. Niinpä talven 1951/52 aikana noin p u o l e e n harventuneesta 1. kylvön kasvustosta saatiin vielä erittäin hyvä (2 753 $\mathrm{kg} / \mathrm{ha}$ ) siemensato.

\section{Vuonna 1951 Jokioisiin perustettu koe}

Vuonna 1951 perustettiin Jokioisten kartanon maalle samanlainen kylvöaikakoe kuin Saloon. Kylvöajat ja koejäsenet olivat samat kuin em. kokeessa. Planet 
Taulukko 4. Sokerijuurikkaan talvehtimiskoe Jokioisissa v. 1951/52. Siemensadot ja sadon laatu. Table 4. Overeintering experiment with sugar beet at Jokioinen in 1951/52. Yields and quality of seed.

\begin{tabular}{|c|c|c|c|c|c|c|c|c|c|}
\hline & \multicolumn{3}{|c|}{$\begin{array}{l}\text { 1. kylvö } 28 / 6 \\
\text { 1st seeding }\end{array}$} & \multicolumn{3}{|c|}{$\begin{array}{l}\text { 2. kylvö } 13 / 7 \\
\text { 2nd seeding }\end{array}$} & \multicolumn{3}{|c|}{$\begin{array}{l}\text { 3. kylvö } 3 / 8 \\
\text { 3rd seeding }\end{array}$} \\
\hline $\begin{array}{l}\text { Koejäsen } \\
\text { Treatment }\end{array}$ & $\begin{array}{l}\text { Siemen- } \\
\text { sato } \\
\text { Yield } \\
\text { of seed } \\
\mathrm{kg} / \mathrm{ha}\end{array}$ & $\begin{array}{c}\text { Itä- } \\
\text { vyys } \\
\text { Germi- } \\
\text { nation } \\
\%\end{array}$ & $\begin{array}{c}1000 \\
\text { s.p. } \\
\text { Weight } \\
\text { of } 1000 \\
\text { seeds } \\
\text { g }\end{array}$ & $\begin{array}{c}\text { Siemen- } \\
\text { sato } \\
\text { Yield } \\
\text { of seed } \\
\mathrm{kg} / \mathrm{ha}\end{array}$ & $\begin{array}{c}\text { Itä- } \\
\text { vyys } \\
\text { Germi- } \\
\text { nation } \\
\%\end{array}$ & $\begin{array}{c}1000 \\
\text { s.p. } \\
\text { Weight } \\
\text { of } 1000 \\
\text { seeds } \\
\text { g }\end{array}$ & $\begin{array}{c}\text { Siemen- } \\
\text { sato } \\
\text { Yield } \\
\text { of seed } \\
\mathrm{kg} / \mathrm{ha}\end{array}$ & $\begin{array}{c}\text { Itä- } \\
\text { vyys } \\
\text { Germi- } \\
\text { nation } \\
\%\end{array}$ & $\begin{array}{c}1000 \\
\text { s.p. } \\
\text { Weight } \\
\text { of } 1000 \\
\text { seeds } \\
\text { g }\end{array}$ \\
\hline \multicolumn{10}{|c|}{$\mathrm{Mu} 1 \mathrm{ta}$ a maton Uncovered } \\
\hline $\mathrm{A}=\mathrm{O}$ & $439 \pm 136$ & 10 & 13.3 & $92 \pm 56$ & 15 & 21.0 & $1161 \pm 472$ & 12 & 21.0 \\
\hline $\mathrm{B}=\mathrm{NPK}$ & $261 \pm 233$ & 11 & 20.3 & $161 \pm 83$ & $12^{\circ}$ & 16.8 & $2869 \pm 339$ & 16 & 16.8 \\
\hline $\begin{array}{l}\text { Keskim. } \\
\text { Average }\end{array}$ & $350 \pm 191$ & 11 & 16.8 & $127 \pm 70$ & 14 & 18.9 & $2015+410$ & 14 & 18.9 \\
\hline \multicolumn{10}{|c|}{ Mullattu Covered } \\
\hline A & $339 \pm 300$ & 12 & 19.8 & $117 \pm 64$ & 8 & 17.8 & $814 \pm 331$ & 10 & 18.0 \\
\hline B & $208 \pm 39$ & 7 & 15.8 & $481 \pm 113$ & 9 & 18.3 & $1300 \pm 172$ & 11 & 18.8 \\
\hline $\begin{array}{l}\text { Keskim. } \\
\text { Average }\end{array}$ & $274 \pm 214$ & 10 & 17.8 & $354 \pm 92$ & 9 & 18.1 & $1057 \pm 263$ & 11 & 18.4 \\
\hline
\end{tabular}

Junior-kylvökoneella suoritetut kylvöt onnistuivat yleensä hyvin ja edullisten kasvuolojen vallitessa taimettuminen edistyi ripeästi. 1. kylvön juurikkaat saavuttivat syksyyn mennessa $6-7 \mathrm{~cm}$ :n läpimitan, 2 . kylvön juurikkaat $\mathrm{n} .4 \mathrm{~cm}$ :n sekä 3. kylvön juurikkaat n. $2 \mathrm{~cm}: n$ läpimitan. Jo heti alkutalvesta taimisto joutui kovalle koetukselle, sillä maan ollessa lumettomana oli kovia pakkasia, joiden aikana maa jäätyi jopa $10 \mathrm{~cm}$ :n syvyydeltä sulaen taas välillä. Kasvusto paljastui lumen alta huhtikuun alkupuoliskolla. Talven aikana olivat 1. ja 2. kylvön multaamattomat sekä mullatut kasvustot kärsineet erittäin pahasti, ja vain jokin taimi oli siellä täällä jäljellä. Kolmannen kylvön kasvusto sen sijaan oli talvehtinut varsin hyvin, multaamaton ehkä hiukan paremmin kuin mullattu. Eri lannoitusruutujen talvehtimisessa ei voitu havaita selviä eroja. Huonoon talvehtimiseen on saattanut vaikuttaa paitsi epäedulliset sääolot ja juurikkaiden huomattava koko varsinkin 1. kylvön ruuduissa (halkaisija $6-7 \mathrm{~cm}$ ), myös se, että juurikkaat harvennettiin edellisenä kesänä (vrt. 2, p. 13-14).

Epäedullisista sääoloista johtuen kasvusto ei lainkaan tuleentunut. Tämän vuoksi niitettiin vain $\mathrm{O}$ - ja NPK-ruudut (=A ja B) 20. 9. Saatu siemen on erittäin huonosti itävää, kuten selviää taulukosta 4 , jossa myös esitetään siemensadot.

Kuten taulukosta 4 ilmenee, 1. ja 2. kylvön kasvustojen siemensato on jäänyt huonon talvehtimisen vuoksi varsin mitättömäksi (multaamattomilla ruuduilla 350 ja $127 \mathrm{~kg} / \mathrm{ha}$, mullatuilla ruuduilla $274 \mathrm{ja} 354 \mathrm{~kg} / \mathrm{ha}$ ). Kolmannen kylvön kasvustosta sen sijaan on saatu multaamattomilta ruuduilta suorastaan hyvä siemensato (2015 kg/ha), mullatuilta puolta huonompi (1 $057 \mathrm{~kg} / \mathrm{ha})$. Siementen itävyydet ovat kuitenkin olleet erittäin alhaiset (keskim. 9-14\%), samoin 1000 siemenen painot 
melko vaatimattomat (16.8-18.9 g), mikä johtuu harvinaisen epäedullisista sääoloista kasvukauden 1952 aikana.

\section{Yhteenveto}

Käsillä olevassa julkaisussa on esitetty päätulokset niistä sokerijuurikkaan talvehtimiskokeista, jotka on perustettu Suomen Raakasokeritehdas Osakeyhtiön toimesta vuonna 1950 Saloon ja v. 1951 Saloon sekä Jokioisiin, ja joiden kokeiden tarkoituksena on ollut selvitellä, voidaanko Suomessa tuottaa sokerijuurikkaan siementä kasvupaikallaan talvehtineista juurikkaista. Näiden alustavien kokeiden perusteella saadut päätulokset esitetään seuraavassa tiivistetyssä muodossa.

Vuosina 1950/51 ja 1951/52 saatujen, tosin vähäisten kokemusten mukaan näyttää siltä, että Lounais-Suomessa on ainakin sääoloiltaan edullisina vuosina mahdollisuuksia tuottaa sokerijuurikkaan siementä kasvupaikallaan talvehtineista juurikkaista, kunhan talvehtimiseen vaikuttavien seikkojen merkitys saadaan riittävästi selvitetyksi. Tärkein viljelyteknillinen tekijä sokerijuurikkaan talvehtimisen varmentamiseksi on ollut oikeaan aikaan suoritettu kylvö. Parhaiten ovat kaikissa neljässä kokeessa talvehtineet juurikkaat, joiden keskimääräinen läpimitta on ollut noin $2 \mathrm{~cm}$. Halkaisijan kasvaessa kolmeen ja neljään $\mathrm{cm}$ :iin on talvehtiminen yleensä ollut varsin selvästi huonompi, samoin myös juurikkaan läpimitan jäädessä kovin pieneksi, alle $0.5 \mathrm{~cm}$. Parhaiten talvehtineiden kasvustojen keskimääräiset talvehtimisprosentit ovat vaihdelleet $66-84 \%$, huonoimmin talvehtineiden kasvustojen $46-66 \%$ (huomioon ottamatta Jokioisten koetta, jossa juurikkaiden läpimitta 1. ja 2. kylvön ruuduissa oli lähinnä harventamisen vuoksi kokonaista $4-7 \mathrm{~cm}$ ja jossa harventaminen on saattanut vaikuttaa heikentävästi talvehtimiseen). Kun huonoimmin talvehtineista kasvustoistakaan ei ole tuhoutunut kuin keskimäärin noin tai lähes puolet, niistä on saatu selvästi parempia siemensatoja (n. $2600-2700$ $\mathrm{kg} / \mathrm{ha}$ ) kuin parhaiten talvehtineista kasvustoista (n. $2200 \mathrm{~kg} / \mathrm{ha}$ ), joiden talvehtimisprosentti on ollut noin 75 .

Multaus on jossain määrin parantanut huonoimmin talvehtineiden suurimpien juurikkaiden talvehtimista, mutta alentanut pienimpien juurikkaiden talvehtimisprosenttia. Satotuloksiin multaus sen sijaan on kaikissa tapauksissa, ja nimenomaan pienimpien juurikkaiden kohdalla, vaikuttanut yleensä erittäin haitallisesti siitä huolimatta, että liika maa haravoitiin mullattujen juurikkaiden päältä keväällä ja että ne lannoitettiin salpietarilla.

Siemensadon laatu, lähinnä itävyys on ollut v. 1951 varsin tyydyttävä (74$93 \%$ ), v. 1952 sen sijaan poikkeuksellisen epäedullisten sääolojen vuoksi huono $(47-60 \%$, Jokioisissa vain $9-14 \%)$.

Sokerijuurikkaan talvehtimiskokeita jatkettaessa on tarkoitus kiinnittää päähuomio niiden seikkojen selvittelyyn, jotka ratkaisevimmin vaikuttavat talvehtimiseen sekä juurikkaista saatavaan siemensatoon ja sen laatuun. Näistä lienevät kylvöaika, kylvömäärä, käytettävä kanta, lannoitus, maan kosteusolot ja kasvukunto yleensä, sekä multaus tärkeimmät. 


\title{
KIRJALLISUUSLUETTELO
}

(1) Mantere, Martti 1948. Sokerijuurikas. Siemenviljelyn opas, Helsinki.

(2) Tolman, Bion ja Smith, Clifton H. 1943. Sugar Beet Seed Growing in Utah. Utah State Agricult. College, Extension Service, p. $1-22$.

(3) Wood, R. R., Brewbaker, H. E. ja Busk, H. L. 1950. Cold Resistanc $\curvearrowright$ in Sugar Beets. Erip., 1950 Proceedings, American Society of Sugar Beet Technologists, p. 116-121.

\section{SUMMARY}

\section{ON THE POSSIBILITY OF PRODUCING SUGAR BEET SEED IN FINLAND FROM BEETS OVERWINTERING IN THE FIELD}

\author{
Juhani Paatela, Helvi Eskola and Martti Mantere
}

This paper contains the chief results of the overwintering experiments with sugar beet which were established through the Suomen Raakasokeritehdas Osakeyhtiö (Finnish Raw Sugar Factory Ltd.) at Salo in 1950, and at Salo and Jokioinen in 1951. The purpose of these experiments was to find out whether sugar beet seed can be produced in Finland from beet overwintering in the field. The results were as follows:

1. Judging by the preliminary experiences of $1950 / 51$ and $1951 / 52$, it seems that at least where are favourable overwintering conditions in Southwest Finland there is some possibility of producing sugar beet seed from beets overwintering in the field, provided the importance of the factors affecting overwintering are sufficiently understood. The most important feature of the cultural technique for securing overwintering of sugar beet was seeding at the proper time. In all four experiments, beets with an average diameter of about $2 \mathrm{~cm}$. overwintered best of all. With a diameter of up to three or four cm. the percentages overwintering generally showed a distinct reduction, as was also the case if the diameter of the beet remained very small, less than $0.5 \mathrm{~cm}$. The average overwintering percentages in the best cases varied from 66 to 84 per cent, in the poorest cases from 46 to 66 per cent (with the exception of the experiment at Jokioinen, where the diameter of the beets of the first and second seedings was as great as 4-7 $\mathrm{cm}$., primarily owing to thinning, and where thinning may have had a detrimental effect on overwintering). As the destruction in the stands with poorest overwintering and biggest beets was on the average about 50 per cent, they have produced distinctly better yields of seed (about $2600-2700 \mathrm{~kg}$. per ha.) than the stands (diameter of roots about $2 \mathrm{~cm}$.) with best overwintering (about $2200 \mathrm{~kg}$. per ha.), where the proportion of overwintering was about 75 per cent.

2. To some extent covering improved the overwintering of the largest beets with the poorest overwintering, but reduced the overwintering percentage of the smallest beets. On the other hand, covering had an extremely detrimental influence on the yields in all cases, and especially with regard to the smallest beets; in spite of the fact that the superfluous soil was raked away in spring and that they were fertilized with sodium nitrate.

3. The quality of the yield of seed, primarily its germinability, was very satisfactory in $195 l^{\prime}(74-$ 93 per cent), but in 1952 poor owing (47-60 per cent, at Jokioinen only 9 - 14 per cent) to exceptionally unfavourable weather conditions.

The chief purpose of future experiments will be to find out what factors have the most decisive influence on overwintering and on yields as well as on seed quality of sugar beets. The most important of these factors are probably date of seeding, amount seeded, strain, fertilization, growth conditions and covering. 